\title{
Zachowane baldachimy procesyjne na terenie Małopolski z wieku XVII i XVIII
}

Pośród bogatego zespołu zachowanych paramentów liturgicznych, reprezentujących małopolskie rzemiosło artystyczne z wieku XVII i XVIII, ważne miejsce zajmują baldachimy procesyjne [il. 1]. Zaskakujące jest to, że o ile trudno wyobrazić sobie dynamikę życia liturgicznego bez używania baldachimu podczas różnorodnych procesji, o tyle ich istnienie, forma, kształt czy też walory artystyczne nie znalazły do tej pory właściwego ich randze zainteresowania w gronie badaczy zajmujących się rzemiosłem artystycznym ${ }^{1}$. Na ich temat pobieżne informacje można znaleźć jedynie w kolejnych tomach Katalogu zabytków sztuki w Polsce lub też w okazjonalnych notach katalogowych, towarzyszących ich prezentacji na wystawach sztuki sakralnej². Podstawowe informacje na temat baldachimów podają jedynie opracowania encyklopedyczne i leksykony³. Wydaje się, że przyczynę tego stanu rzeczy

1. Baldachimów procesyjnych nie uwzględnili w swoich przekrojowych opracowaniach rzemiosła artystycznego znawcy tematu: A. Bochnak, K. Buczkowski, Rzemiosło artystyczne w Polsce, Warszawa 1971; J. Samek, Polskie rzemiosło artystyczne. Czasy nowożytne, Warszawa 1984, czy też Z. Żygulski jr., Dzieje polskiego rzemiosła artystycznego, Warszawa 1987.

2. Na przykład XVIII-wieczny baldachim w Kacwinie omówiony w: J. Daranowska-Łukaszewska, Baldachim procesyjny, w: Wawel 10oo-20oo. Skarby archidiecezji krakowskiej, t. 2: Katalog, red. J. A. Nowobilski, Kraków 2000, s. 255, il. 693.

3. Por. np. W. Łuszczkiewicz, Baldachim, w: Encyklopedia staropolska ilustrowana, red. Z. Gloger, t. 1, Warszawa 1900, s. 98-101; A. Brückner, Encyklopedia staropolska, t. 1: A-M, Warszawa 1937-1939, s. 66-67; Ch. Zieliński, Sztuka sakralna, Poznań-Warszawa-Lublin 1960, s. 195-196; F. Mąkinia, M. Pisarzak, Baldachim, w: Encyklopedia katolicka, t. 1, red. F. Gryglewicz, Lublin 1985, kol. 1275-1276; Słownik terminologiczny sztuk pięknych, red. K. Kubalska-Sulkiewicz, M. Bielska-Łach, 
należy upatrywać w dużych stratach w obrębie zachowanego materiału zabytkowego. Baldachimy procesyjne, wykonywane z zasady z nietrwałych materiałów, skazane były na szybkie zużycie oraz naturalną degradację substancji konstrukcyjnej, wynikające z narażenia na opady deszczu podczas procesji, podarcia i inne uszkodzenia mechaniczne powstałe przy przenoszeniu lub składaniu. Dlatego stosunkowo często zaplamione i potargane baldachimy zastępowano nowymi, a stare palono ${ }^{4}$. W takim przypadku jedynym śladem ich istnienia są archiwalne zdjęcia przechowywane w archiwach służb konserwatorskich ${ }^{5}$.

Przeprowadzona kwerenda udowodniła, że także źródła archiwalne nie były dla baldachimów łaskawe, gdyż mówią o nich zdawkowo, a jeśli już podają więcej informacji, to są one przeważnie bardzo ogólnikowe ${ }^{6}$. Celem niniejszego opracowania jest próba omówienia zachowanych baldachimów procesyjnych z wieku XVII i XVIII z terenu Małopolski, które udało się zlokalizować w wyniku przeprowadzonej kwerendy. Dotyczy to także baldachimów ze spiskich parafii, powiązanych kulturowo z Małopolską, mimo że te tereny w interesującym nas okresie wchodziły w skład archidiecezji ostrzyhomskiejł.

Baldachim (baldach), określany także jako "niebo", "podniebienie", "podniebie", stanowi dekoracyjną, przenośną osłonę wykonaną z tkaniny rozpiętej na czterech lub sześciu drzewcach (laskach). Jego boki najczęściej zdobione są lambrekinem lub frędzlami ${ }^{8}$ Sama nazwa pochodzi

A. Manteuffel-Szarota, Warszawa 2005, s. 30; B. Nadolski, Leksykon liturgii, Poznań 2006, s. 133 .

4. Taki los w ostatnich latach spotkał np. XVIII-wieczne baldachimy w Niedzicy i Łapszach Niżnych oraz w Bielanach koło Kęt.

5. W tym miejscu chciałbym wyrazić swoją wdzięczność Joannie Hiżyckiej z Wojewódzkiego Małopolskiego Urzędu Ochrony Zabytków w Krakowie za pomoc przy przeprowadzeniu kwerendy oraz udostępnienie zdjęć archiwalnych do publikacji.

6. Wyjątek stanowią np. opisy baldachimów w inwentarzu z roku 1620, 1692, 1702, 1761, 1791, będących na wyposażeniu katedry krakowskiej. Zob. Inwentarze katedry krakowskiej z lat 1586, 1620 i 1692, opr. A. Perzanowska, Kraków 2014, s. 157, 239-240; Inwentarze skarbca katedry krakowskiej z lat 1702, 1761 i 1791, opr. A. Perzanowska, Kraków 2016, s. 78-79, 183-184, 249-250.

7. Por. B. S. Kumor, Dzieje diecezji krakowskiej do roku 1795, t. 1, Kraków 1998, s. 135139; T. M. Trajdos, Szkice z dziejów Zamagórza, Kraków 1991, passim; H. Ruciński, Dzieje późnośredniowiecznego Spisza, w: Historia Scepusii, t. 1, red. A. Gabryś, S. A. Sroka, M. Starzyński, Bratislava-Kraków 2010, s. 400-412.

8. Baldachimów w kościołach chrześcijańskich używa się jako osłony przedmiotów kultu. Mogą być przenośne, montowane na stałe, nadwieszane lub podpierane. Od sposobu ich umiejscowienia zależny jest ich kształt, który może przybierać formę rozpiętej draperii, kopuły lub płaskiego daszku, czego przykładu dostarczają 



1. Procesja Bożego Ciała w Kacwinie, fot. B. Kalfas
2. Baldachim w typie umbelli, XVII w., Muzeum w Raciborzu, fot. B. Kalfas 
od łacińskiego słowa baldac ${ }^{9}$ określającego Bagdad, gdzie produkowano dwukolorowy, kosztowny brokat nazywany baldachem. Baldachimy o mniejszych rozmiarach określano jako umbella lub umbrella, gdyż miały kształt parasola $^{10}$. Popularne od starożytności baldachimy trafiły do Europy w okresie wypraw krzyżowych, wtedy też pojawiły się w liturgii rzymskiej". Począwszy od wieku XII ważną rolę odgrywały baldachimy ustawiane lub też noszone nad dostojnikami świeckimi i duchownymi, których użycie podnosiło rangę celebrowanych we wnętrzach uroczystości ${ }^{12}$. Szczególne miejsce zajmowały

niezachowane bardzo okazałe baldachimy zdobiące np. ołtarze katedry na Wawelu. Według inwentarza z roku 1692 baldachimy były m.in. przeznaczone do ozdoby grobu św. Stanisława - jeden z fundacji Aleksandra Michała Lubomirskiego (zm. 1677), wojewody krakowskiego, drugi z fundacji Marianny z Tarłów (zm. po 1690), żony Mikołaja Jana Lanckorońskiego (zm. 1673), starosty nowokorczyńskiego i trzeci wykonany z czerwonej tkaniny damasceńskiej. Kolejne wykonano do ozdoby ołtarza głównego, ołtarza cyborialnego i ołtarza Krzyża Świętego. Zob. Inwentarze katedry krakowskiej z lat 1586..., dz. cyt., s. 239-240. Istnieją także baldachimy w formie architektonicznej, stanowiące oprawę dla posągów, a w większej skali wsparte na kolumnach lub filarach były wznoszone nad nagrobkami lub konfesjami, jak stało się to w przypadku nagrobków królewskich i konfesji św. Stanisława w katedrze na Wawelu. Drewniane baldachimy stosowano w stallach, ambonach itp. Od wieku XII baldachimy z tkaniny lub drewna były także częścią składową łóżka i tronu. Por. W. Łuszczkiewicz, Baldachim, dz. cyt., s. 98-101; A. Brückner, Encyklopedia staropolska, dz. cyt., s. 66-67; F. Mąkinia, M. Pisarzak, Baldachim, dz. cyt., kol. 1275-1276; Słownik terminologiczny..., dz. cyt., s. 30; B. Nadolski, Leksykon..., dz. cyt., s. 133.

9. Baldachimy określano również z łaciny jako: baldachinus, bandequinus, coelum, conopeum, mappula, pannus, pallium, papilio, umbraculum. Por. A. Jougan, Słownik kościelny łacińsko-polski, Poznań-Warszawa-Lublin 1958, s. 65; B. Nadolski, Leksykon..., dz. cyt., s. 133.

10. Por. W. Łuszczkiewicz, Baldachim, dz. cyt., s. 99.

11. Por. F. Mąkinia, M. Pisarzak, Baldachim, dz. cyt., kol. 1275-1276; B. Nadolski, Leksykon..., dz. cyt., s. 133.

12. Do baldachimów tronowych odnosi się zapewne zapis z inwentarza katedry krakowskiej z roku 1620, mówiący o baldachimach wykonanych z altembasu i teletu, zdobionych haftem z przedstawieniem herbów Królestwa Polskiego, Wielkiego Księstwa Litewskiego i Królowej Bony. Zob. Inwentarze katedry krakowskiej z lat $1586 \ldots$, dz. cyt., s. 157. Innego przykładu dostarcza zachowany baldachim z koronacji króla Augusta III Sasa w roku 1734 zdobiący do dziś katedrę krakowską. Por. J. Lileyko, Regalia polskie, Warszawa 1987, s. 11, il. 7-8, il. 44; M. Rożek, Królewska katedra na Wawelu, Warszawa 1981, s. 118, il. 11. Baldachimy tronowe poświadcza także bogata ikonografia, np. drzeworyty ilustrujące koronację Bolesława Chrobrego w Chronica Polonorum Macieja Miechowity z roku 1521 i w Kronice wszystkiego świata Marcina Bielskiego z roku 1564, gdzie Chrobry klęczy przed zasiadającym na tronie pod baldachimem cesarzem Ottonem III lub sztych pochodzący z norymberskiej oficyny drukarskiej Christiana Sigmunda Frobera z roku 1697, ilustrujący Wjazd Augusta II na koronację do Krakowa w roku 1697 oraz sam akt 
baldachimy procesyjne w kolorze białym lub złotym noszone nad kapłanem podczas procesji z Najświętszym Sakramentem. Ich powszechność związana była z rozwojem kultu Bożego Ciała i nakazywanych przez prawodawstwo kościelne procesji teoforycznych. W okresie gotyku była to czworokątna osłona z brokatu w białym kolorze, która w następnych wiekach ewoluowała, przyjmując różne formy. Rozpięte na stelażach kosztowne tkaniny ozdabiano dodatkowo aplikacjami i haftami tematycznie związanymi z Eucharystią ${ }^{13}$. Stąd też baldachimy procesyjne były na stanie wyposażenia prawie każdej świątyni parafialnej lub zakonnej (por. Aneks, tabl. 1-3).

W zależności od stopnia hierarchicznego kościoła baldachim mógł mieć 4, 6 lub 8 drążków. Podczas procesji teoforycznej kościoły kolegiackie miały prawo do używania baldachimu wspartego na sześciu drążkach, natomiast kościoły parafialne mogły mieć baldachim wsparty tylko na czterech ${ }^{14}$. Warto w tym miejscu przywołać ilustrację procesji Bożego Ciała we Fromborku prowadzoną przez bp. Michała Stefana Radziejowskiego z ok. 1683-1685, ukazaną przez działającego na Warmii Georga Pipera (Frombork, kościół katedralny pw. Wniebowzięcia NMP i św. Andrzeja Apostoła) ${ }^{15}$. Przedstawiony tu baldachim stanowi usztywnioną konstrukcję, wspartą na czterech czerwonych drążkach, na przedłużeniu których ponad stelażem widoczne są spłaszczone kule z puklowanymi zakończeniami. Boki tworzy zapewne haftowany złocisty lambrekin o prostokątnych zakończeniach. Obiekt ten doskonale charakteryzuje baldachimy barokowe, które zaczęto wykonywać z ciężkiego brokatu, często zdobionego haftem o motywach eucharystycznych (chrystogram "IHS", symbol Najświętszego Serca Pana Jezusa, Ducha Świętego, kłosy zbóż i winne grona itp.) ${ }^{16}$.

W procesjach mniej uroczystych, np. przy zanoszeniu wiatyku chorym, używano małego baldachimu początkowo czworokątnego na dwóch drążkach,

koronacji króla (Warszawa, Muzeum Narodowe), gdzie ukazano wnętrze katedry udekorowanej królewskim baldachimem oraz orszak z osobą króla prowadzonego pod przenośnym baldachimem.

13. Por. F. Mąkinia, M. Pisarzak, Baldachim, dz. cyt., kol. 1276.

14. Por. W. Łuszczkiewicz, Baldachim, dz. cyt., s. 99; Ch. Zieliński, Sztuka sakralna, dz. cyt., s. 195.

15. Por. J. Żmudziński, Procesja Bożego Ciała we Fromborku prowadzona przez biskupa Michała Stefana Radziejowskiego, w: Święto baroku. Sztuka w służbie prymasa Michała Stefana Radziejowskiego (1645-1705), red. J. Żmudziński, Warszawa 2009, s. $78-83$, il. s. 79 i 81.

16. Por. Ch. Zieliński, Sztuka sakralna, dz. cyt., s. 195; F. Mąkinia, M. Pisarzak, Baldachim, dz. cyt., kol. 1276. 
a następnie $\mathrm{w}$ formie parasola - umbelli ${ }^{17}$. Czerwone baldachimy noszono nad relikwiami Krzyża Świętego oraz narzędziami męki Pańskiej, natomiast w Wielki Piątek baldachmimy musiały być fioletowe ${ }^{18}$. Baldachimów nie wolno było nosić nad relikwiami i obrazami świętych. Przykład purpurowej umbelli z pogranicza śląsko-małopolskiego z wieku XVII zachował się np. w zbiorach Muzeum w Raciborzu [il. 2]. Swoim kształtem przypomina bęben zawieszony za pomocą lnianych taśm na jednym, trzymetrowym drążku zwieńczonym krzyżem. Boki wykonano z prostokątnych kawałków aksamitu wełnianego, zdobiąc je płaskim haftem srebrnym, miejscami na podkładzie z tektury. Łączenia poszczególnych części przykryto złotym galonem, a następnie całość przymocowano do drewnianej konstrukcji wykonanej z giętych na parze cieniutkich deseczek łączonych rafią. Spód umbelli ozdobiono galonem oraz frędzlami i czerwonymi chwostami, a jej górną cześć przytwierdzonymi wotami z wieku XVII i XVIII, które obok jej koloru świadczą, że baldachim noszono nad relikwiami Krzyża Świętego ${ }^{19}$. Podobną umbellę, niesioną w procesji z relikwiami Krzyża Świętego, wyobraża miedzioryt G. de Groosa z roku 1699, zdobiący wydany w Pradze Rytuał z roku $1700^{20}$. Od wieku XVI w Kościele baldachimu używało się także w czasie ingresu biskupa, jednak jego kolor nie był sprecyzowany ${ }^{21}$.

Baldachimy procesyjne najczęściej umieszczano pod chórem muzycznym, w tzw. babińcu lub pod wieżą kościoła. Do reformy liturgicznej Soboru Watykańskiego II (1962-1965) stanowiły obok kościelnych ław, chorągwi i latarni procesyjnych stały element wyposażenia kościelnych wnętrz, nadając im charakterystyczny koloryt, co ilustrują np. archiwalne zdjęcia nieistniejących już dziś baldachimów we wnętrzu kościoła św. Bartłomieja w Niedzicy, św. Kwiryna w Łapszach Niżnych albo zdjęcie szczęśliwie zachowanego baldachimu w kościele św. Stanisława we Frydmanie ${ }^{22}$.

Mówiąc o baldachimach procesyjnych, trzeba pamiętać, iż są wytworami powstałymi na styku różnych technik artystycznych, takich jak: tkactwo, hafciarstwo, snycerstwo czy też kowalstwo, co wielokrotnie nastarczało

17. Por. F. Mąkinia, M. Pisarzak, Baldachim, dz. cyt., kol. 1276.

18. Por. Ch. Zieliński, Sztuka sakralna, dz. cyt., s. 195.

19. Za udzielone informacje oraz materiał fotograficzny umbelli z Raciborza dziękuję Barbarze Kalfas, która przeprowadziła jej konserwację.

20. Ritualis sue Agendae Romano-Pragensis [...], Pragae 1700, s. 186.

21. Por. F. Mąkinia, M. Pisarzak, Baldachim, dz. cyt., kol. 1276

22. Archiwum fotograficzne Wojewódzkiego Urzędu Ochrony Zabytków w Krakowie - Frydman, Łapsze Niżne, Niedzica. 
trudności z ich zaklasyfikowaniem do konkretnej grupy paramentów liturgicznych, stanowiących wyposażenia prawie każdego kościoła. Stąd też inwentarze, zwłaszcza zachowane w wizytacjach biskupich, przyporządkowuja je albo do grupy przedmiotów drewnianych, albo tekstyliów, a najczęściej do zbioru przedmiotów różnych (varia suppellex). Szczegółowszych informacji odnoszących się do wyglądu lub materiału, z którego baldachimy procesyjne na terenie Małopolski były wykonane, dostarczają opisy inwentarzowe z wieku XVIII ${ }^{23}$. Na ich podstawie można podjacć próbę sformułowania ogólnej charakterystyki będących na stanie wyposażenia kościoła baldachimów, które z kilkoma tylko wyjątkami nie dotrwały do naszych czasów. Oczywiście istotną rolę odgrywały tu możliwości finansowe potencjalnych fundatorów lub parafialnej społeczności, co przekładało się na jakość powstających obiektów.

Na podstawie źródeł oraz zachowanych przykładów z interesującego nas terenu baldachimy procesyjne pod względem kształtu można podzielić na dwie grupy. Pierwszą, najliczniejszą, stanowią baldachimy na rzucie prostokąta zbliżonego do kwadratu o drewnianym lub metalowym stelażu, zaopatrzone w dwa lub cztery drążki (laski). Drugą natomiast baldachimy owalne na jednym drążku w kształcie parasola, określane jako umbella. W obu grupach najistotniejszym elementem dekoracyjnym była tkanina rozpięta na stelażu tworząca podniebie oraz dach baldachimu, kształtując także jego boki za pomocą falbany lub lambrekinu.

Niezwykle okazale musiały wyglądać np. niezachowane do naszych czasów baldachimy procesyjne z katedry krakowskiej. Były wykonane z kosztownego, wzorzystego teletu ${ }^{24}$, żółtej kitajki ${ }^{25}$, brokatu (burkateli) ${ }^{26}$ lub białej lamy. Dodatkowo dekorowała je złota lub czerwona frędzla, galon, chwosty, aplikacje lub hafty z motywem kwiatów, czy też np. haft z motywem herbu Lubicz biskupa krakowskiego Piotra Tylickiego (zob. Aneks, tab. 3) ${ }^{27}$.

Na prowincji używano tekstyliów mniej kosztownych. Podniebie i dach baldachimu wykonywano najczęściej z dwóch różnych tkanin (np. baldachimy

23. Dla zilustrowania tego zagadnienia wykorzystano przykładowo inwentarze skarbca katedry krakowskiej z roku 1702, 1761 i 1791 oraz wizytacje biskupie dekanatu oświęcimskiego i zatorskiego z lat 1747-1748.

24. Telet - bardzo kosztowna tkanina jedwabna sprowadzana ze Wschodu i Włoch.

25. Kitajka - tkanina jedwabna, chińska.

26. Burkatela (brokat, brokatela) - tkanina jedwabna lub półjedwabna, gorszego gatunku, wielowątkowa i dwuosnowowa.

27. Zob. Inwentarze katedry krakowskiej z lat 1586..., dz. cyt., s. 157; Inwentarze skarbca katedry krakowskiej z lat 1702..., dz. cyt., s. 78-79, 183-184, 249-250. 
w Oświęcimiu, Suchej Beskidzkiej, Stryszowie, Palczy) ${ }^{28}$. Zdarzało się, że dach zabezpieczano przed zamoczeniem woskowaniem (np. baldachim w Kętach) ${ }^{29}$. Najczęściej stosowano płótno, które mogło być malowane (np. baldachimy w Tylmanowej, Chochołowie, Bielanach) ${ }^{30}$, atłas ${ }^{31}$, adamaszek ${ }^{32}$, aksamitt ${ }^{33}$, kitajkę, nędzę ${ }^{34}$, tercynellę ${ }^{35}$, tkaniny parterowe ${ }^{36}$ i półjedwabne ${ }^{37}$. Zastosowane tkaniny były jednokolorowe - białe, niebieskie, czerwone, zielone lub też różnokolorowe, często we wzorzyste kwiaty (np. baldachimy w Szaflarach, Rabce, Kleczy, Inwałdzie) ${ }^{38}$ albo w pasy (np. baldachimy w Wieprzu, Andrychowie, Radoczy) ${ }^{39}$ i prążki (np. baldachim w Palczy, Spytkowicach) ${ }^{40}$ (zob. Aneks, tab. 1-2).

Dach baldachimu najczęściej był płaski, ale występowały także przykłady o dynamicznych formach, jak np. baldachim w Pisarzowicach: „Baldachim na obłąkach puklasty z czterema drzewcami malowanymi z haczykami żelaznymi"4. Dodatkowo stosowano dekoracyjne uzupełnienia w postaci obszycia galonem, koronką, frędzlą, taśmami i haftem, np. z przedstawieniem

28. Zob. Archiwum Kurii Metropolitalnej w Krakowie, AV 35, s. 36 (55), 73 (471), 134 (478), $502(817)$.

29. Zob. Archiwum Kurii Metropolitalnej w Krakowie, AV 35, s. 209 - „z wierzchu płótno czarne woskowane".

30. Zob. Archiwum Kurii Metropolitalnej w Krakowie, AV 52, k. 2, k. 19; AV 35, s. 102 (100).

31. Atłas - tkanina jedwabna o silnym połysku.

32. Adamaszek - droga tkanina jedwabna, wyrabiana w Damaszku, najczęściej szkarłatna z wzorem matowym z liści, kwiatów, owoców, dwustronna z wzorem matowym na lśniącym tle lub odwrotnie.

33. Aksamit - tkanina jedwabna lub bawełniana, z włosem (grec. hexamiton - z sześciu nici, starofranc. samit).

34. Nędza - rodzaj tkaniny jedwabnej; były nędze bogate i ubogie.

35. Tercynella - tkanina jedwabna.

36. Tkanina parterowa - tkanina różnokolorowa z kompozycją geometryczną.

37. Szerzej to zagadnienie omówiono m.in. w: Zarys historii włókiennictwa do końca XVIII wieku na ziemiach polskich, red. J. Kamińska, I. Turnau, Wrocław-Warszawa-Kraków 1966. W niniejszym opracowaniu wyjaśnienie rodzaju tkanin pochodzi ze słownika nazw tkanin i innych przedmiotów zamieszczonego w: Inwentarze katedry krakowskiej z lat 1586..., dz. cyt., s. 253-258; Inwentarze skarbca katedry krakowskiej z lat 1702..., dz. cyt., s. 301-306.

38. Zob. Archiwum Kurii Metropolitalnej w Krakowie, AV 52, k. 13v, 32v; AV 35, s. 49 (303), 286 (579).

39. Zob. Archiwum Kurii Metropolitalnej w Krakowie, AV 35, s. 305 (598), 324 (617), 381 (695).

40. Zob. Archiwum Kurii Metropolitalnej w Krakowie, AV 35, s. 502 (817), 520 (835).

41. Archiwum Kurii Metropolitalnej w Krakowie, AV 35, s. 434 (749). 
Najświętszego Serca Jezusa (np. baldachim w Bielanach) ${ }^{42}$, a także chwostami. Występowały także baldachimy wzbogacone o zawieszane firanki (np. baldachim w Spytkowicach) ${ }^{43}$. Dach baldachimu mógł być dekorowany czterema lub dwoma złoconymi kulami z puklowaniem na przedłużeniu drążków (np. baldachim w Stryszowie, Radoczy) ${ }^{44}$, bądź też posiadać zwieńczenie w formie ażuru roślinno-kwiatowego rzeźbionego i złoconego w drewnie, obiegającego wszystkie boki. Drzewce od baldachimu mogły być proste lub też rzeźbione i malowane (np. baldachim w Pisarzowicach) ${ }^{45}$.

Pierwszą grupę o kształcie czworobocznym reprezentuje tylko kilka zachowanych baldachimów z omawianego terenu. Ze względu na formę stelaża i sposób zamocowania tkaniny można w niej wyróżnić cztery podtypy.

Podtyp pierwszy tworzy grupa baldachimów w całości wykonanych z tekstyliów zawieszonych na niewidocznym stelażu, mocowanym na mniej lub bardziej zdobionych drążkach. Szczególne miejsce zajmuje tu najstarszy z zachowanych w Małopolsce baldachimów procesyjnych w drewnianym kościele św. Mikołaja w Polance Wielkiej, który spośród pozostałych obiektów ma najlepszą metrykę źródłową [il. 3-4]. Przeprowadzona kwerenda archiwalna pozwala stwierdzić, że baldachim powstał przed rokiem 1663, kiedy to wzmiankowany jest po raz pierwszy jako "Baldachimo noviter comparatur" w wizytacji biskupiej Mikołaja Oborskiego, przeprowadzonej w dekanacie zatorskim w latach 1663-166 $5^{46}$. Występuje także w spisie inwentarzowym z roku 1663 wykonanym przez ówczesnego proboszcza polańskiego ks. Tobiasza Zaboklickiego (zm. 1691), gdzie określono go jako „baldach nowy"47. Wzmiankowany jest również jako „Baldachimo" w inwentarzu sprzętów kościelnych w późniejszej wizytacji z lat 1708 $-1709^{48}$ oraz wspomniany przez bp. Michała

42. Zob. Archiwum Kurii Metropolitalnej w Krakowie, AV 35, s. 102 (100) - „na podniebieniu serce srebrne szyte".

43. Zob. Archiwum Kurii Metropolitalnej w Krakowie, AV 35, s. 520 (817) - „Baldachim kitajką czerwoną okryty. Firanki do niego w prąszki zielone czerwone złotem przerobione z koronką w koło szychową".

44. Zob. Archiwum Kurii Metropolitalnej w Krakowie, AV 35, s. 134 (478) - "na wierzchu zaś cztery gałki złotem malarskim wyzłocone"; "na wierzchu gałeczki cztery malarskim złotem wyzłocone" - s. 381 (695).

45. Zob. Archiwum Kurii Metropolitalnej w Krakowie, AV 35, s. 434 (749).

46. Zob. Archiwum Kurii Metropolitalnej w Krakowie, AV 8, k. 35.

47. Archiwum Parafialne w Polance Wielkiej, Inwentarz sprzętów kościelnych z roku 1663, brak numeracji stron.

48. Zob. Archiwum Kurii Metropolitalnej w Krakowie, AV 16, k. 25v. 
Kunickiego w wizytacji z roku 1729 jako "Baldachim materialny"49. Tę samą informację podaje pod datą 11 stycznia 1734 roku w inwentarzu parafialnym proboszcz ks. Sebastian Żurkowski (zm. 1748) ${ }^{50}$, jednakże już w wizytacji biskupa krakowskiego Andrzeja Stanisława Załuskiego wizytator 7 września

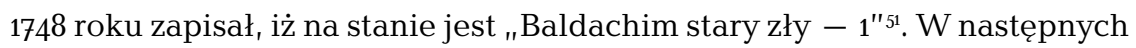
latach baldachim jest wzmiankowany po raz ostatni przez proboszcza Jana Antosiewicza (zm. 1866) w roku 1852 w Spisie Aparatów Kościelnych w Polance Wielkiej w Roku 1852, obok nowego baldachimu określonego jako „Baldach z Kutaszami galonowymi... i okryciem na nim - 1", jako "Baldach stary także z nakryciem -1 "52.

Baldachim z Polanki Wielkiej reprezentuje klasyczny przykład baldachimu barokowego ${ }^{53}$. Jego podniebie, rozpięte na zbliżonym do kwadratu stelażu, wykonano z aksamitu, niegdyś różowego, obecnie beżowego, ozdobionego aplikacjami z tkaniny brokatowej srebrnej na podkładzie z waty bawełnianej. Podniebie zostało ozdobione haftem wypukłym z motywem słonecznej glorii otaczającej chrystogram „IHS" zdobiony krzyżykiem

49. Archiwum Kurii Metropolitalnej w Krakowie, AVCap. 61, k. 607.

50. Zob. Archiwum Parafialne w Polance Wielkiej, Descrypcya kościoła Polońskiego pod tytułem Świętego Mikołaja Biskupa Mireńskiego przez Jaśnie Wielmożnego IMCi Pana Kaspra na Cieni Cieńskiego Łowczego Nadwornego koronnego kolatora d. 11 Stycznia Roku P. 1734. X Sebastyanowi Żurkowskiemu Plebanowi teraźniejszemu conferowanego dawno już circiter intra et extra cum attinentijs zdezelowanego, dopieroż przez tegoż X. Żurkowskiego Plebana Introdukcyi własnym jego kosztem y straniem a fundamentis podważanego, brak numeracji stron [pisownia zgodna z oryginałem].

51. Archiwum Kurii Metropolitalnej w Krakowie, AV 35, s. 711 (396).

52. Archiwum Parafialne w Polance Wielkiej, Spis Aparatów Kościelnych w Polance Wielkiej w Roku 1852, brak numeracji stron [pisownia zgodna z oryginałem]. Wszystko wskazuje na to, że wymieniony nowy baldachim pojawił się w Polance ok. 1841 roku, kiedy to proboszcz Jan Antosiewicz zapisał "Gałki i drążki do nowego baldachu tychże wyzłocenie -9 fr. 52 kr. Przykrycie na Baldachim nowy -2 fr. 40 kr." (Archiwum Parafialne w Polance Wielkiej, Spis wydatków znaczniejszych, na kościół, rzeczy kościelne, Reperacyje Plebanii, budynków gospodarskich w Polance Wielkiej, przez ks. Jana Antosiewicza od Roku 1841. Własnym kosztem uskuteczniony, t. 19, s.1).

53. Bardzo zniszczony baldachim był przechowywany na stryszku zakrystii nieużywanego od początku lat 80. XX wieku drewnianego, dawnego kościoła parafialnego św. Mikołaja w Polance Wielkiej, nie będąc uwzględniony w żadnym opracowaniu. Dzięki staraniom ówczesnego proboszcza ks. prałata Tadeusza Porzyckiego Barbara Kalfas przeprowadziła jego konserwację zakończoną w grudniu 2016 roku. Informacje na temat baldachimu polańskiego zawarte w niniejszym opracowaniu oraz materiał fotograficzny ilustrujący zakres prac pochodzą od Barbary Kalfas, której serdecznie dziękuję za ich udostępnienie. 

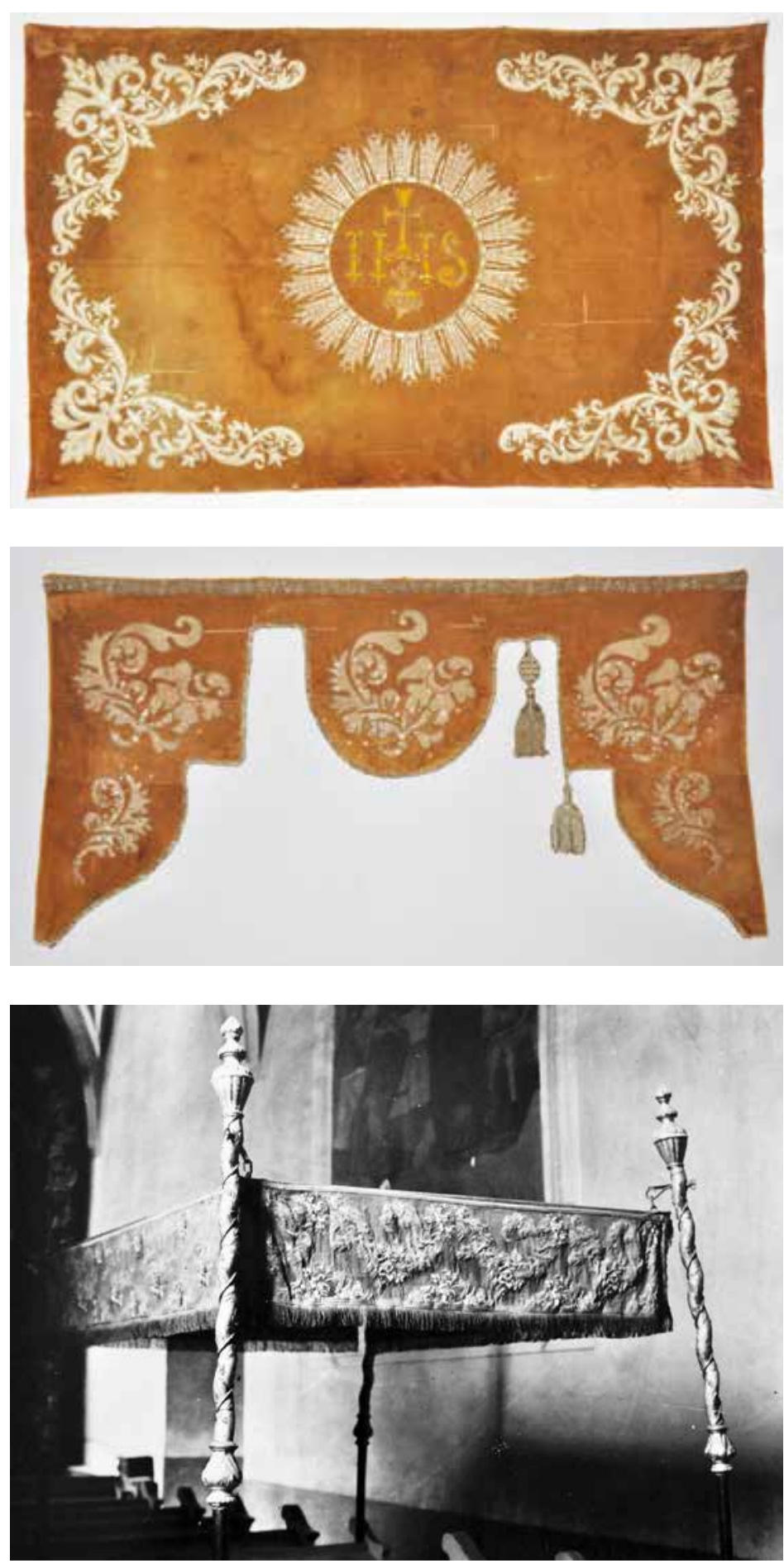

3. Podniebie baldachimu, 1663, kościół św. Mikołaja w Polance Wielkiej, fot. B. Kalfas
4. Lambrekin baldachimu, 1663, kościół św. Mikołaja w Polance Wielkiej, fot. B. Kalfas

5. Baldachim, kon. XVIII w., kościół par. św. Bartłomieja w Niedzicy (niezachowany), fot. Archiwum WUOZ w Krakowie 
i wyobrażeniem Najświętszego Serca Pana Jezusa oraz umieszczonymi w narożach ornamentami roślinnymi [il. 3], charakterystycznymi dla haftu XVII-wiecznego ${ }^{54}$. Dach baldachimu uszyto z żółtej, być może włoskiej, wełnianej tkaniny o wzorze z motywami roślinno-kwiatowo-owocowymi, który wtórnie został dodatkowo obwiedziony haftem łańcuszkowym z różowego jedwabiu i nitki srebrnej. Do podniebia za pomocą kościanych guzików przypięto boki w formie lambrekinu, wykrojonego z jedwabnego aksamitu, z aplikacjami z tkaniny brokatowej [il. 4]. Dodatkowo lambrekin zdobiony był większymi i mniejszymi srebrnymi chwostami przytwierdzonymi do niewielkiej plecionki, której kształt i splot zdradzają wpływ Orientu, podobnej np. do ornamentów dekorujących tureckie karwasze od zbroi z wieku XVII (Muzeum Narodowe w Krakowie - Zbiory Czartoryskich, nr inw. XIV.295/1,2) oraz górną część wykonanego na Bałkanach w wieku XVII czekana, wg tradycji będącego zdobyczą wiedeńską Jana III Sobieskiego (klasztor OO. Paulinów na Jasnej Górze w Częstochowie) ${ }^{55}$.

Taki sam kształt, co w Polance Wielkiej uzyskał niezachowany baldachim w kościele św. Bartłomieja w Niedzicy z końca wieku XVIII, wzmiankowany jeszcze w roku $1953^{56}$ [il. 5]. Najprawdopodobniej był to obiekt aksamitny, być może czerwony, zawieszony na czterech, w górnych częściach spiralnie skręconych drążkach o tralkowych zakończeniach ${ }^{57}$. Skromniejszą wersję tego rozwiązania pod względem wielkości stanowi jedyny zachowany w Krakowie z omawianego okresu baldachim w kolegiacie św. Anny. Jego boki wykonano z fragmentów tkaniny wg tradycji ofiarowanej kolegiacie przez króla Jana III Sobieskiego, z której uszyto także garnitur szat liturgicznych (kapę, ornat i dwie dalmatyki) ${ }^{58}$. Baldachim o wtórnym żółtym, prostokątnym podniebiu o wklęsłych rogach, dekorowany aplikowaną glorią słoneczną z haftowanym chrystogramem „IHS" otrzymał czerwone aksamitne boki pokryte dekoracją roślinno-kwiatową. Są one haftowane złotą nicią, w stylistyce tureckiej,

\footnotetext{
54. Por. J. Samek, Polskie rzemiosło..., dz. cyt., s. 179.

55. Por. Odsiecz wiedeńska 1683. Wystawa jubileuszowa w Zamku Królewskim na Wawelu w trzechsetlecie bitwy. Tło historyczne i materiały źródłowe, t. 1-2, red. A. Franaszek, K. Kuczman, Kraków 1990, s. 278, il. 347, s. 289, il. 361.

56. Zob. Katalog zabytków sztuki w Polsce, t. 1: Województwo krakowskie, red. J. Szablowski, Warszawa 1953, s. 363 .

57. Zob. Archiwum fotograficzne Wojewódzkiego Urzędu Ochrony Zabytków w Krakowie - Niedzica.

58. Zob. Katalog zabytków sztuki w Polsce, t. 4: Miasto Kraków, cz. 2: Kościoły i klasztory śródmieścia 1, red. A. Bochnak, J. Samek, Warszawa 1971, s. 92.
} 

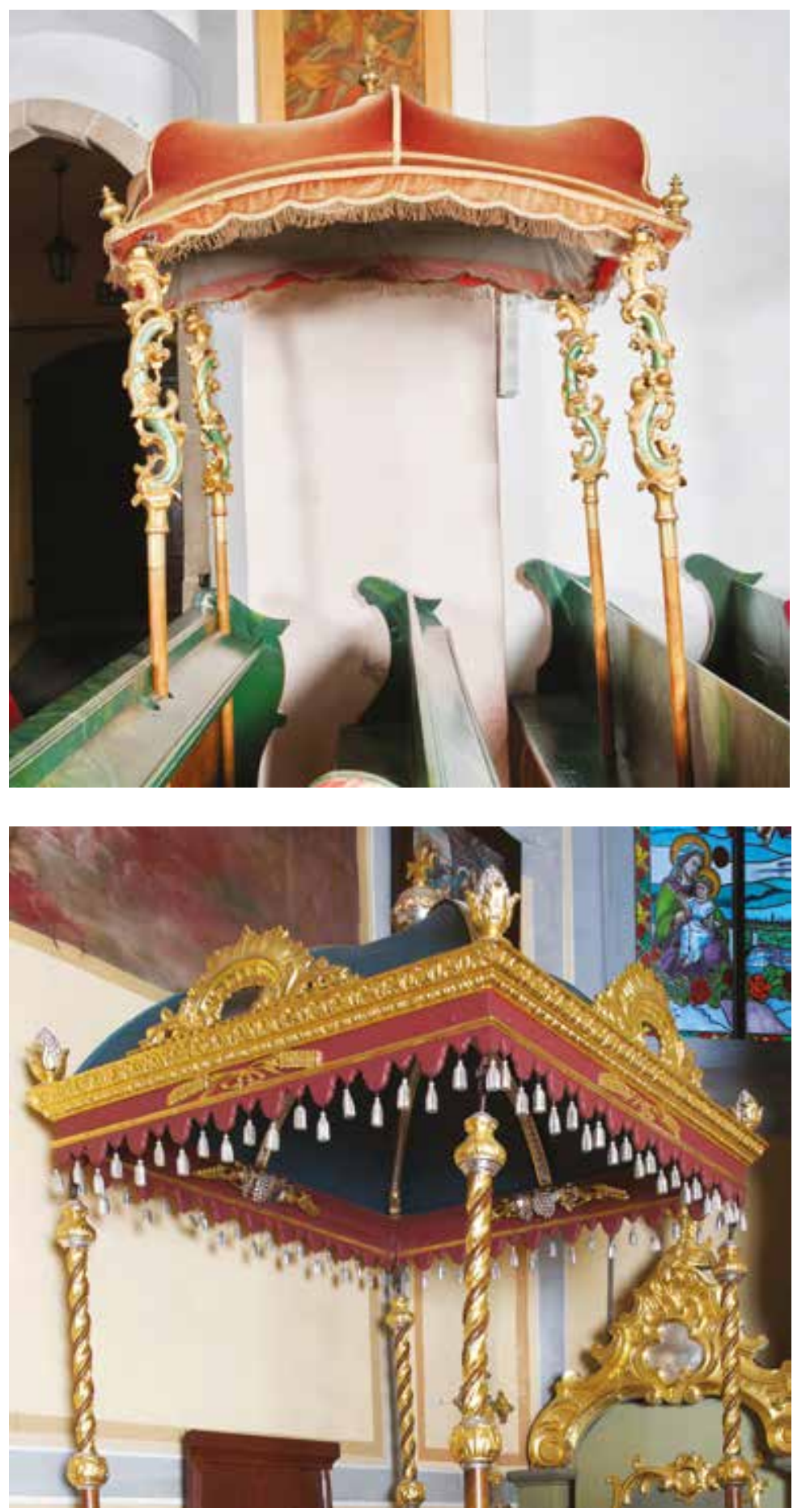

6. Baldachim, 2. poł. XVIII w., kościół par. Wszystkich Świętych w Kacwinie, fot. R. Nestorow
7. Baldachim, 2. poł. XVIII w., kościół par. św. Marcina w Krempachach, fot. R. Nestorow 
przypominającą ornamentykę występującą na borcie i kapturze aksamitnej kapy tureckiej z końca wieku XVI (Muzeum Diecezjalne w Przemyślu, nr inw. $255)^{59}$. Dolne krawędzie boków ozdobiono złotym galonem i czerwonymi frędzlami. Baldachim przeznaczony jest do noszenia na dwóch drążkach.

Drugi podtyp reprezentuje baldachim w kościele parafialnym Wszystkich Świętych w Kacwinie, datowany na druga połowę wieku XVIII, który mógł powstać zarówno na terenie Małopolski, jak i też dawnych Górnych Węgier [il. 6] ${ }^{60}$. Jego stelaż posiada stalową konstrukcję złożoną z ośmiu żeber w kształcie połowy łuku w ośli grzbiet, przytwierdzonych do obręczy zbliżonej formą do prostokąta o lekko wypukłych bokach. Całość pokryto bordowym, dziś spłowiałym aksamitem, z którego również wykonano dolną falbanę obszytą galonem i złotymi frędzlami. Obszycie galonem poprowadzono także po żebrach oraz wzdłuż obręczy. Podniebie zostało wyścielone błękitnym atłasem przykrytym białym tiulem. W narożach obręczy baldachimu oraz na szczycie przy łączeniu żeber zamocowano mosiężne cebulaste sterczyny. Baldachim za pomocą metalowych koluszek oraz haków jest zawieszony na czterech drążkach w górnych partiach złoconych i laserwanych kolorem zielonym, pokrytych bogato rzeźbioną dekoracją z motywem rocalliowym oraz gałązek z kwiatem róży. W dolnej części laski są gładkie, malowane na czerwono. Zbliżony kształt posiadał wspomniany już baldachim wzmiankowany źródłowo w Pisarzowicach ${ }^{61}$.

Trzeci podtyp tworzą cztery rokokowe spiskie baldachimy zachowane w kościele św. Stanisława we Frydmanie (2. poł. XVIII w. $)^{62}$, św. Marcina w Krempachach (2. poł. XVIII w.) [il. 7] $]^{63}$ i św. Elżbiety w Trybszu (2. poł. XVIII w. ${ }^{64}$ oraz znany ze zdjęć archiwalnych niezachowany baldachim z końca XVIII wieku w kościele św. Kwiryna w Łapszach Niżnych ${ }^{65}$, istniejący jeszcze

59. Por. Odsiecz wiedeńska 1683..., dz. cyt., s. 322, il. 397.

6o. Zob. Katalog zabytków sztuki w Polsce, t. 1, dz. cyt., s. 357; J. Daranowska-Łukaszewska, Baldachim procesyjny, dz. cyt., s. 255, il. 693; Zabytki sztuki w Polsce. Małopolska, red. W. Bałus, J. Wolańska, Warszawa 2016, s. 503.

61. Zob. Archiwum Kurii Metropolitalnej w Krakowie, AV 35, s. 434 (749).

62. Zob. Katalog zabytków sztuki w Polsce, t. 1, dz. cyt., s. 352; Zabytki sztuki w Polsce..., dz. cyt., s. 376 .

63. Zob. Katalog zabytków sztuki w Polsce, t. 1, dz. cyt., s. 358; Zabytki sztuki w Polsce..., dz. cyt., s. 713 .

64. Por. Zabytki sztuki w Polsce..., dz. cyt., s. 1438.

65. Zob. Archiwum fotograficzne Wojewódzkiego Urzędu Ochrony Zabytków w Krakowie - Łapsze Niżne. 
w roku $1953^{66}$. Podobny, ale niestety dziś już nieistniejący baldachim poświadczony źródłowo w roku 1747 jako „Baldachim snycerską robote malowany wszystek 1" był w kościele parafialnym Wszystkich Świętych w Wieprzu koło Andrychowa ${ }^{67}$.

Zasadniczym elementem dekoracyjnym wymienionych baldachimów jest mniej lub bardziej bogato rzeźbiony i złocony drewniany stelaż, do którego przytwierdzany był dach wykonany z tkaniny bądź też z deski, jak w przypadku baldachimu w Trybszu i być może w Łapszach Niżnych. W stelażu można wyróżnić dwie części. Czworoboczną ramę na rzucie zbliżonym do kwadratu (w Łapszach Niżnych niegdyś o ściętych narożach) w formie profilowanego gzymsu zdobionego dodatkowo ornamentem roślinnym, jak w przypadku baldachimu w Krępachach [il. 7] oraz zamocowany poniżej drewniany lambrekin, dekorowany drewnianymi, złoconymi chwostami. Ponad gzymsem pośrodku poszczególnych boków zamocowano dekoracje roccalliowe, natomiast na jego narożnikach rzeźbione szyszki w akantowych kielichach (niezachowane we Frydmanie, co potwierdzają zdjęcia archiwalne). Podniebie drewniane było w Trybszu oraz zapewne w Łapszach Niżnych, gdzie zdobiło je iluzjonistyczne malowidło. We Frydmanie i Krempachach podniebie utworzone zostało ze skrzyżowanych czterech stalowych prętów podtrzymujących bordowy i ciemnozielony atłas półjedwabny. Na skrzyżowaniu prętów w obu przypadkach zamocowano stylizowany glob z krzyżykiem opleciony koroną cierniową. Dodatkowo stelaż baldachimu w Krępachach ozdobiono rzeźbionymi kłosami oraz winnymi gronami [il. 7].

Omówione baldachimy wiesza się na czterech złoconych i malowanych laserunkiem drewnianych drążkach. W Trybszu i Krempachach ich górne części przyjmują formę spiralną, zamkniętą u spodu spłaszczonymi kulami dekorowanymi ornamentem liściastym. Dodatkowo w Krempachach drążki zwieńczone są spłaszczonymi kulami z puklowaniem, do których przymocowano metalowe uchwyty podtrzymujące baldachim. We Frydmanie górne partie gładkich drążków oplata rzeźbiona delikatna wić w formie liściastych gałązek.

Spośród baldachimów spiskich wyróżniał się niezachowany już dziś baldachim w Łapszach Niżnych, dekorowany malowidłem umieszczonym na podniebiu, wykonanym zapewne na płótnie [il. 8]. Była to iluzjonistyczna

66. Zob. Katalog zabytków sztuki w Polsce, t. 1, dz. cyt., s. 360.

67. Archiwum Kurii Metropolitalnej w Krakowie, AV 35, s. 305 (598). 
dekoracja, utworzona z otwierającego się na niebo zwielokrotnionego gzymsowania, artykułowanego profilowanymi konsolami - płaskim na środku, a półokrągłymi (na wzór tromp) w narożach, podtrzymującymi wazy z kwiatami. W centrum podniebia przytwierdzono rzeźbioną gołębicę symbolizującą Ducha Świętego, otoczoną przez promienie. W malowidle dominowały brązy, bordo i róż oraz pośrodku jasny ugier, a w narożach barwy szaro-błękitne ${ }^{68}$. Dekoracja podniebia w swoim wyrazie formalnym była zbliżona do iluzjonistycznych malowideł występujących w malarstwie ściennym na terenie Moraw i dawnych Górnych Węgier, szczególnie popularnych od początku wieku XVIII. Powstające w tym czasie dekoracje bardzo często uciekały się do imitowania elementów architektonicznych mających budować złudzenie powiększenia przestrzeni ${ }^{69}$. Jako przykład można przywołać projekt iluzjonistycznego fresku nieznanego artysty z lat 1730-1740 Apollo i Muzy (Muzeum Narodowe w Krakowie) $)^{70}$ lub też rozwiązania zastosowane na sklepieniu nawy krakowskiego kościoła Przemienienia Pańskiego autorstwa Franciszka Ecksteina i Józefa Piltza z Moraw z roku $1733^{71}$.

Wreszcie czarty podtyp reprezentuja zachowane dwa rokokowe baldachimy z kościoła św. Anny w Nowym Targu z drugiej połowy XVIII wieku ${ }^{72}$ oraz Trójcy Przenajświętszej w Krzywaczce z trzeciej ćwierci XVIII wieku ${ }^{73}$ [il. 9]. Jest to charakterystyczne połączenie bogato rzeźbionego rokokowego stelażu, przyjmującego formę ażurowego obramienia wieńczącego dach, połączonego z materiałowym podniebiem oraz zawieszonymi bokami (obecnie

68. Zob. Archiwum Wojewódzkiego Urzędu Ochrony Zabytków w Krakowie - Łapsze Niżne, Baldachim procesyjny - Karta ewidencyjna zabytku ruchomego.

69. Szerzej to zagadnienie omówiono m.in. w: Skarby baroku - między Bratysława a Krakowem, red. T. Zaucha, J. Wolańska, Kraków 2017, s. 69-77.

70. Por. Skarby baroku..., dz. cyt., s. 76, il. s. 74-75.

71. Por. T. Dobrowolski, Sztuka Krakowa, Kraków 1959, s. 428; Katalog zabytków sztuki ${ }_{W}$ Polsce, t. 4: Miasto Kraków, cz. 3: Kościoły i klasztory śródmieścia 2, red. A. Bochnak, J. Samek, Warszawa 1987, s. 100 il. 286; Zabytki sztuki w Polsce..., dz. cyt., s. $620-621$.

72. Zob. Katalog zabytków sztuki w Polsce, t. 1, dz. cyt., s. 368. Być może baldachim nowotarski jest tożsamy z obiektem wymienianym w wizytacji z 1765 roku jako "Baldachim nowy" (Archiwum Kurii Metropolitalnej w Krakowie, AV 52, k. 10). Obecnie dach tego baldachimu został wtórnie zamontowany nad miejscem przewodniczenia w prezbiterium kościoła.

73. Zob. Katalog zabytków sztuki w Polsce, t. 1, dz. cyt., s. 271; Zabytki sztuki w Polsce..., dz. cyt., s. 749. Datowanie niezwykle dekoracyjnego baldachimu w Krzywaczce zdaje się potwierdzać brak jego odnotowania w wizytacji biskupiej z roku 1748. Zob. Archiwum Kurii Metropolitalnej w Krakowie, AV 36, k. 30v. 
wtórnym). Oryginalne boki z tkaniny historycznej, podobnie jak i drążki, nie zachowały się w obu przypadkach. Znamy je tylko ze zdjęć archiwalnych ${ }^{74}$. Szczególnie dekoracyjne jest obramienie baldachimu w Krzywaczce. Tworzy go grubo rzeźbiony, złocony, ażurowy ornament roccalliowy, łączący cztery narożniki przerwanego gzymsu, zwieńczone wazonami płomienistymi [il. 9].

Do drugiej grupy należy zaliczyć baldachimy o kształcie owalnym, mające formę rozkładanego i składanego parasola. Taki niezachowany baldachim poświadczony jest np. źródłowo w kościele parafialnym św. Jana Chrzciciela w Zembrzycach ${ }^{75}$. Być może ten sam kształt miał baldachim używany w drodze z Najświętszym Sakramentem do chorych, wzmiankowany w inwentarzu katedry krakowskiej z roku 1702 oraz drugi, podobny ujęty w inwentarzu z roku 1761 i $1791^{76}$. Podobna XVIII-wieczna umbella jeszcze do niedawna znajdowała się w kościele parafialnym św. Macieja Apostoła w Bielanach koło Kęt. Niestety znana jest jedynie ze zdjęć archiwalnych i opisu ${ }^{77}$ [il. 10]. W tym przypadku na drewnianej konstrukcji o dziewięciu szprosach (dwa były złamane), usadowionych koliście wokół centralnego drążka, rozpięto tkaninę rypsową z nicią srebrną w kolorze beżowo srebrnym, podbitą od spodu czerwonym jedwabiem. Całość była obszyta złotym galonem, spod którego widoczne były drobne frędzle. W szczycie znajdował się kulisty otwór także obszyty tym samym galonem. Drążek i szprosy pomalowane były na kolor szaro-zielony. Kształt baldachimu oraz sposób jego składania i rozkładania nasuwa skojarzenia z popularnymi w tym czasie w Europie parasolami chińskimi i japońskimi, których przedstawienia można znaleźć chociażby na docierającej do nas z Dalekiego Wschodu porcelanie lub japońskich drzeworytach. Jako przykład warto tu przywołać scenę rodzajową $\mathrm{z}$ widocznym parasolem zdobiącą jedną z waz w typie famille rose z epoki Quing, okres Yongzheng, 1723-1735 (Kraków, Muzeum Narodowe, nr inw. MNK VI-6741/1ab-2ab) ${ }^{78}$ lub też japoński, barwny drzeworyt na papierze Isoda

74. Zob. Archiwum fotograficzne Wojewódzkiego Urzędu Ochrony Zabytków w Krakowie - Krzywaczka, Nowy Targ (kościół pw. św. Anny).

75. Zob. Archiwum Kurii Metropolitalnej w Krakowie, AV 35, s. 103 (447): „Baldachim okrągły kitaykowy w niebieskie y żółte breciki z frandzlą w koło złoto jedwabną -1 ".

76. Zob. Inwentarze skarbca katedry krakowskiej z lat 1702..., dz. cyt., s. 79, 183, 250.

77. Zob. Katalog zabytków sztuki w Polsce, t. 1, dz. cyt., s. 8; Archiwum Wojewódzkiego Urzędu Ochrony Zabytków w Krakowie - Bielany koło Kęt, Baldachim procesyjny - Karta ewidencyjna zabytku ruchomego.

78. Por. W przestrzeni smoka. Sztuka chińska w zbiorach Muzeum Narodowego w Krakowie, red. A. Biedrzycka, M. Kołpanowicz, Kraków 2015, s. 176 (nr katalogu 121) i s. 318. 
8. Podniebie baldachimu,

kon. XVIII w., kościół

par. św. Kwiryna w Łapszach

Niżnych (niezachowany),

fot. Archiwum WUOZ w Krakowie
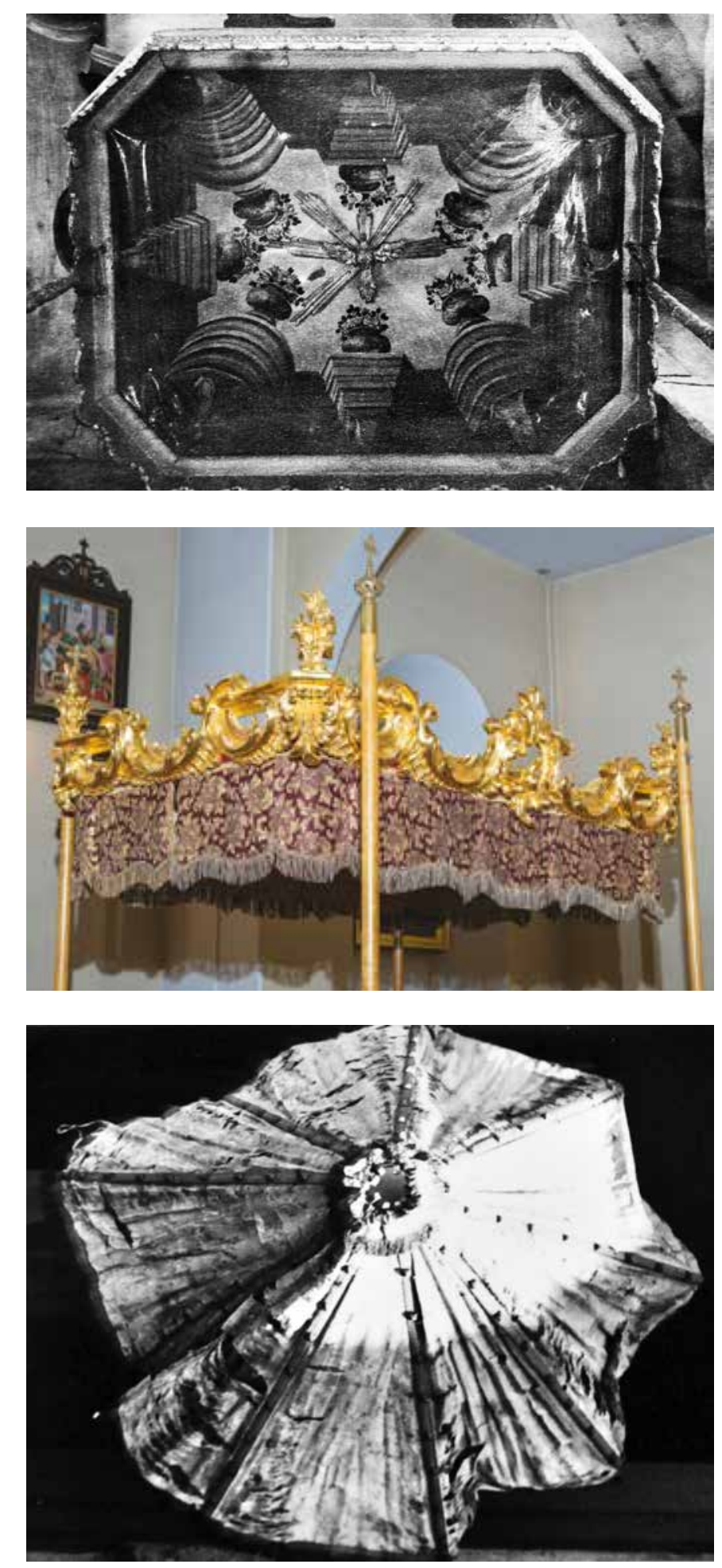

10. Baldachim, XVIII w., kościół par. św. Macieja w Bielanach k. Kęt (niezachowany), fot. Archiwum WUOZ w Krakowie
9. Baldachim, 3. ćw. XVIII w., kościół par. Trójcy Przenajświętszej w Krzywaczce, fot. R. Nestorow 
Koryŭsai (1735-1790), ukazujący Dziewczynę w białej szacie pod parasolem

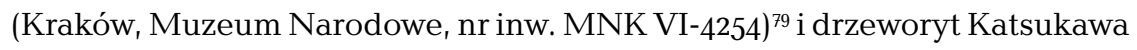
Shun'ei (1762-1819), przedstawiający parasol w scenie Aktorzy Segawa Kikunojŏ $i$ Yoshizawa Ayama jako Ohatsu i Iwafuji w scenie dramatu Kagamiya, z ok. 1795 (Kraków, Muzeum Narodowe, nr inw. MNK VI-982ab) ${ }^{80}$.

Powstające w następnych dwóch stuleciach baldachimy generalnie przyjęły kształt prostokąta zbliżonego do kwadratu, z drewnianym lub metalowym stelażem, z tekstylnym dachem i bokami prostymi lub w formie lambrekinu, jak np. baldachim z opactwa SS. Norbertanek w Imbramowicach z roku 1851, haftowany przez s. Elżbietę Lekszycką z fundacji ksieni imbramowickiej Bronisławy Świtanowskiej $(1848-1866)^{81}$, o czym świadcza umieszczone na jednym z boków jej inicjały B.S.K.I. i rok $1851^{82}$. Występowały także baldachimy, w których do elementów tekstylnych dodawano akcenty snycerskie, czego przykładem może być XIX-wieczny baldachim w kościele św. Mikołaja w Sidzinie ${ }^{83}$. Jego dach jest zwieńczony w formie polichromowanego, złoconego i srebrzonego, ściętego graniastosłupa, z umieszczonym na wierzchołku leżącym na zamkniętej księdze z siedmioma pieczęciami pełnoplastycznym Barankiem Apokaliptycznym. Na ściankach bocznych znalazły się płaskorzeźbione, polichromowane i złocone uskrzydlone główki aniołków. Drewniane podniebie zostało udekorowane rzeźbionym i srebrzonym wyobrażeniem gołębicy w promienistej glorii. Ciekawy przykład stanowi baldachim z drewnianym, złoconym stelażem na rzucie krótkiego prostokąta, w który wpisano owal z tekstylnym dachem i bokami, mocowany do dwóch drążków. Ufundował go do kościoła Świętego Krzyża w Starej Wsi w roku 1869 Jan Nycz, co potwierdza napis fundacyjny na jego dachu: „Fundator tego Baldachu Jan Nycz R. 1869 Gur.". (Muzeum Parafialne w Starej Wsi). Z tego okresu nie są już znane baldachimy w formie parasola, co wskazuje, że były one ciekawym wytworem rzemiosła artystycznego wieku XVIII.

79. Zob. B. Romanowicz, Onna. Piękno - siła-ekstaza. Drzeworyty i malarstwo japońskie z kolekcji Muzeum Narodowego w Krakowie, Kraków 2017, s. 17, il. I.3.

80. Zob. B. Romanowicz, Onna..., dz. cyt., s. 773, il. IV.7.

81. Por. L. Sobol, Kultura klasztoru ss. Norbertanek w Imbramowicach od poczatku do czasów najnowszych, Kraków 2007, s. 108.

82. Zob. Archiwum klasztoru SS. Norbertanek w Imbramowicach, Inwentarz sprzętów kościelnych w kościele w Imbramowicach z 1862 roku, s. 36.

83. Zob. Archiwum Wojewódzkiego Urzędu Ochrony Zabytków w Krakowie - Sidzina, Baldachim procesyjny - Karta ewidencyjna zabytku ruchomego. 
Zaczerpnięte ze źródeł historycznych opisy baldachimów procesyjnych z wieku XVII i XVIII, jak i zachowane z tego czasu omówione przykłady oraz liczne świadectwa ikonograficzne, pozwalają na lepsze zrozumienie rangi i znaczenia baldachimów procesyjnych nie tylko w obszarze liturgicznych celebracji, w których miały podkreślić wagę sprawowanych obrzędów poprzez dodanie im splendoru, lecz także na płaszczyźnie artystyczno-estetycznej w zakresie rzemiosła, łączącego różne jego dziedziny. Niezależnie od tego, z czego i w jaki sposób baldachimy były wykonywane, trzeba pamiętać, że każdy z zachowanych obiektów, który przetrwał do naszych czasów, zasługuje na szczególną uwagę i troskę, gdyż dzięki nim lepiej możemy zrozumieć bogactwo kultury religijnej w Małopolsce od wieku XVII aż po czasy współczesne. Należy wyrazić nadzieję, że dalsze kwerendy archiwalne oraz poszukiwania i przeprowadzane konserwacje powiększą grupę zachowanych obiektów oraz wiedzę na ich temat, co może w tym zakresie zaowocować ważną publikacją naukową. 


\section{ANEKS}

Tab. 1. Baldachimy procesyjne ujęte w wizytacji dekanatu nowotarskiego z roku 1747-1748 (Archiwum Kurii Metropolitalnej w Krakowie, AV 35)

\begin{tabular}{|c|c|c|c|}
\hline Lp. & Miejscowość & Opis baldachimu & Strona \\
\hline 1. & Włosienica & Baldachium kitajkowe ze dwiema drzewcami & 7 \\
\hline 2. & Oświęcim & $\begin{array}{l}\text { Baldachim nowo sprawiony, podniebienie grodetu- } \\
\text { rowe niebieskie z galonikiem złotym na koło } \\
\text { y przez ośrodek z płotkami w koło u niego } \\
\text { zielonemi parterowemi, koronką złotą szamerowa- } \\
\text { nemi }\end{array}$ & $36(55)$ \\
\hline 3. & $\begin{array}{l}\text { Poręba } \\
\text { Wielka }\end{array}$ & Baldachim jeden & $68(67)$ \\
\hline 4. & Grojec & Baldachim stary & $82(80)$ \\
\hline 5. & Osiek & Baldachim jeden stary drugi nowy. Dobry & $92(90)$ \\
\hline 6. & $\begin{array}{l}\text { Bielany koło } \\
\text { Kęt }\end{array}$ & $\begin{array}{l}\text { 1) Baldachim puklasty malowany spodem na płótnie, } \\
\text { z płotkiem w około szajowym na dwóch drążkach. } \\
\text { 2) Baldachim nowy zielony z galonem srebrnym, } \\
\text { na podniebieniu serce srebrne szyte }\end{array}$ & $102(100)$ \\
\hline 7. & Jawiszowice & Baldachimów materyami podbitych całych 2 & $111(109)$ \\
\hline 8. & Dankowice & Baldachim adamaszkowy z frandzlą jedwabną & $127(125)$ \\
\hline 9. & Stara Wieś & Baldachim adamaszkowy 1 & $139(137)$ \\
\hline 10. & Wilamowice & $\begin{array}{l}\text { Baldachim czerwony na dwóch laskach drewnia- } \\
\text { nych, dobry } 1\end{array}$ & $148(146$ \\
\hline 11. & Nidek & Baldachim czerwony [z] kitajki 1 & $158(156)$ \\
\hline 12. & Pisarzowice & Baldachim czerwony [z] materyi 1 & $168(166)$ \\
\hline 13. & Kozy & Baldachinum procesionale bonum unum & $179(177)$ \\
\hline 14. & Czaniec & Baldachim kitaykowy biały z zielonemi paskami & $188(189)$ \\
\hline 15 . & Kęty & $\begin{array}{l}\text { 1) Baldachim o dwóch laskach pstrey materyi z kran- } \\
\text { cem takimże, z wierzchu płótno czarne, woskowane } \\
\text { 2) Baldachim wielki } 1 \text { (był w posiadaniu konfraterni } \\
\text { różańcowej) }\end{array}$ & 209 \\
\hline 16. & Bulowice & $\begin{array}{l}\text { Baldachim o dwóch laskach, flamele złoto czerwo- } \\
\text { ney, z krancem takimże, jedwabną frandzlą } 1\end{array}$ & $119(235)$ \\
\hline 17. & Witkowice & Baldachim szkotowy z falbanką y frandzelką 1 & 250 \\
\hline 18. & $\begin{array}{l}\text { Marcypo- } \\
\text { ręba }\end{array}$ & Baldachim nędzowy z frandzlą & $7(261)$ \\
\hline 19. & Tłuczań & Baldachim złoty adamaszkowy 1 & $22(276)$ \\
\hline 20. & Witanowice & Brak informacji & \\
\hline
\end{tabular}




\begin{tabular}{|c|c|c|c|}
\hline Lp. & Miejscowość & Opis baldachimu & Strona \\
\hline 21. & Klecza & Baldachim w kwiaty czerwone 1 & $49(303)$ \\
\hline 22. & $\begin{array}{l}\text { Sucha Be- } \\
\text { skidzka }\end{array}$ & $\begin{array}{l}\text { Baldachim adamaszkowy niebieski z frandzlą siecz- } \\
\text { kową, kitajką czerwoną starą podszyty } 1\end{array}$ & $73(417)$ \\
\hline 23. & Krzeszów & Brak informacji & \\
\hline 24. & $\begin{array}{l}\text { Maków } \\
\text { Podhalański }\end{array}$ & Brak informacji & \\
\hline 25. & Sidzina & Brak informacji & \\
\hline 26. & Zembrzyce & $\begin{array}{l}\text { 1) Baldachim adamaszkowy, czerwony, spłowiały } \\
\text { z listwami nędzowemi y frandzlą w koło jedwabną } 1 \\
\text { 2) Baldachim okrągły, kitaykowy w niebieskie y żółte } \\
\text { breciki z frandzlą w koło złoto jedwabną 1 }\end{array}$ & $103(447)$ \\
\hline 27. & Mucharz & $\begin{array}{l}\text { Płotek od Baldachimu czerwony kitaykowy } \\
\text { z frandzlą jedwabną czerwoną } 1\end{array}$ & $121(465)$ \\
\hline 28. & Stryszów & $\begin{array}{l}\text { Baldachim z materyi białey, półjedwabney w różne } \\
\text { kwiaty z kompanką żółtą wenecką spodkiem czer- } \\
\text { woną, bogato podbity na dwóch drążkach na wierz- } \\
\text { chu zaś cztery gałki złotem malarskim wyzłocona }\end{array}$ & $134(478)$ \\
\hline 29. & Zakrzów & Brak informacji & \\
\hline 30. & Barwałd & Baldachin non volet ad usum & $163(457)$ \\
\hline 31. & $\begin{array}{l}\text { Frydrycho- } \\
\text { wice }\end{array}$ & Baldachim nowy y stary 2 & $174(468)$ \\
\hline 32. & Przybradz & Brak informacji & \\
\hline 33. & Woźniki & Brak informacji & \\
\hline 34. & Wadowice & $\begin{array}{l}\text { Baldachim jeden stary drugi nowy z płotkiem ada- } \\
\text { maszkowym czerwonym, frandzlą jedwabną } 2\end{array}$ & $216(509)$ \\
\hline 35. & Ryczów & Baldachim szkotowy 1 & $246(539)$ \\
\hline 36. & Chocznia & $\begin{array}{l}\text { Baldachim u którego są białe pstre z frandzlami } \\
\text { czerwonymi, nieprzystojny stary } 1\end{array}$ & $266(559)$ \\
\hline 37. & Inwałd & $\begin{array}{l}\text { 1) Baldachim atłasowy, czerwony ofrandzlowany } 1 \\
\text { 2) Baldachim niebieski, parterowy w różne kwiaty } 1\end{array}$ & $286(579)$ \\
\hline 38. & $\begin{array}{l}\text { Wieprz koło } \\
\text { Andrychowa }\end{array}$ & $\begin{array}{l}\text { 1) Baldachim kitajki różnego koloru w pasy } 1 \\
\text { 2) Baldachim snycerską robotę malowany wszystek } 1 \\
\text { 3) Baldachim prostey materi stary } 1\end{array}$ & $305(598)$ \\
\hline 39. & Andrychów & $\begin{array}{l}\text { 1) Baldachim adamaszkowy czerwony } 1 \\
\text { 2) Baldachim kitaykowy w pasy różne } 1 \\
\text { 3) Baldachim wielki parterowy złocisty z frandzlą } \\
\text { jedwabną, szrodek atłasowy, czerwony (był w posia- } \\
\text { daniu konfraterni różańcowej) }\end{array}$ & $\begin{array}{l}324(617) \\
332(625)\end{array}$ \\
\hline 40. & Gierałtowice & Brak informacji & \\
\hline 41. & Graboszyce & Baldachim kitaykowy stary, podarty 1 & $366(679)$ \\
\hline 42. & Radocza & $\begin{array}{l}\text { Baldachim kitaykowy w paski w koło galonek szy- } \\
\text { chowy biały na wieszchu gałeczki cztery malarskim } \\
\text { złotem wyzłocone } 1\end{array}$ & $381(695)$ \\
\hline
\end{tabular}




\begin{tabular}{lllc}
\hline Lp. & Miejscowość & Opis baldachimu & Strona \\
\hline 43. & $\begin{array}{l}\text { Polanka } \\
\text { Wielka }\end{array}$ & Baldachim stary, zły 1 & $396(711)$ \\
\hline 44. & Głębowice & $\begin{array}{l}\text { Baldachium tercynelowe zielone z frandzlą czerwo- } \\
\text { ną, jedwabną, złe 1 }\end{array}$ & $415(730)$ \\
\hline 45. & Pisarzowice & $\begin{array}{l}\text { Baldachium na obłąkach puklasty z czterema drzew- } \\
\text { cami malowanymi z haczykami żelaznymi 1 }\end{array}$ & $434(749)$ \\
\hline 46. & Przeciszów & $\begin{array}{l}\text { 1) Baldachim lepszy 1 } \\
\text { 2) Baldachim stary zły 1 }\end{array}$ & $450(765)$ \\
\hline 47. & Zator & Baldachim parterowy z frandzlą & $466(781)$ \\
\hline 48. & Palcza & $\begin{array}{l}\text { Baldachim na dnie niebieski w prąszki, frandzlą } \\
\text { do koła obity o dwóch laskach, dośyć piękny 1 }\end{array}$ & $502(817)$ \\
\hline 49. & Spytkowice & $\begin{array}{l}\text { Baldachim kitajką czerwoną okryty. Firanki do nie- } \\
\text { go w prąszki, także kitaykowe w prążki zielone, } \\
\text { czerwone, złotem przerabiane z koronką w koło }\end{array}$ & $520(835)$ \\
& & szychową 1 & \\
\hline 50. & Bachowice & Brak informacji & \\
\hline
\end{tabular}


Tab. 2. Baldachimy procesyjne ujęte w wizytacji dekanatu nowotarskiego z roku 1765 (Archiwum Kurii Metropolitalnej w Krakowie, AV 52)

\begin{tabular}{llll}
\hline Lp. & Miejscowość & Opis baldachimu & Karta \\
\hline 1. & Tylmanowa & $\begin{array}{l}\text { Baldachim na płótnie malowany o laskach dwóch, } \\
\text { około mający felpanke kitaykową szytą }\end{array}$ & 2 \\
\hline 2. & Krościenko & $\begin{array}{l}\text { Baldachin parterowy z falbanką z podney } \\
\text { o dwóch laskach }\end{array}$ & 4 \\
\hline 3. & Szczawnica & Baldachim & 4 \\
\hline 4. & Nowy Targ & Baldachim nowy & 10 \\
\hline 5. & Szaflary & $\begin{array}{l}\text { Baldachim nowy o dwóch laskach. Felpanka atła- } \\
\text { sowa na dnie karmazynowym w kwiaty }\end{array}$ & $13 \mathrm{~V}$ \\
\hline 6. & Waksmund & Baldachim bez firanek & 14 \\
\hline 7. & Ludźmierz & $\begin{array}{l}\text { Baldachim do noszenia na Procesyą z felpanką } \\
\text { axamitną czerwoną }\end{array}$ & 16 \\
\hline 8. & Czarny Dunajec & Baldachim stary & 19 \\
\hline 9. & Chochołów & Baldachim stary, płócienny & 19 \\
\hline 10. & Raba Wyżna & Baldachin żaden & 19 \\
\hline 11. & Spytkowice & $\begin{array}{l}\text { Baldachim o dwóch laskach, falpanka zielona, } \\
\text { jedwabna w pasy z frandzlą }\end{array}$ & 22 \\
\hline 12. & Jordanów & $\begin{array}{l}\text { Baldachimy dwa jeden o dwóch, drugi o czterech } \\
\text { laskach }\end{array}$ & 27 \\
\hline 13. & Łętownia & $\begin{array}{l}\text { Baldachinum novum (był w posiadaniu konfrater- } \\
\text { ni różańcowej) }\end{array}$ & 31 \\
\hline 14. & Rabka & $\begin{array}{l}\text { Baldachin o dwóch laskach. Felpanka parterowa } \\
\text { w kwiaty }\end{array}$ & $32 \mathrm{~V}$ \\
\hline & & & \\
\hline
\end{tabular}


Tab. 3. Baldachimy w katedrze krakowskiej wg inwentarza z roku 1702, 1761,

$1791^{84}$

\begin{tabular}{ll}
\hline Lp. & Baldachimy procesyjne z roku $\mathbf{1 7 0 2}$ \\
\hline 1. & $\begin{array}{l}\text { Baldakin, którego usus jest super Sanctissimo na processyi w Boże Ciało, } \\
\text { wierzch teletowy złocisty z kwiatami różowemi spłowiałemi mający, kroniec } \\
\text { około niego teletowy czerwony z frędzlą złotą, z herbami śp. J.M.X. Tylickie- } \\
\text { go. }\end{array}$ \\
\hline 2. & $\begin{array}{l}\text { Baldakin zielony lamowy z kwiatami złotemi, z frędzlą i galonem złotym, } \\
\text { wierzch u niego kitajkowy żółty. }\end{array}$ \\
\hline 3. & $\begin{array}{l}\text { Baldakin burkatelowy żółty, z frandzlą jedwabną pstrą, pod którym defertur } \\
\text { Sanctissimum ad infirmos. }\end{array}$
\end{tabular}

4. Baldakin stary na dnie wiśniowy ciemnym spłowiałym, kwiaty złote i jedwabne różnych kolorów mający, z frędzlą jedwabną fiałkową ze złotem.

\begin{tabular}{ll}
\hline Lp. & Baldachimy procesyjne z roku 1761 \\
\hline 1. & Baldachim [ze] złotej lamy, z fręndzlą wokoło złotą, z gałkami drewnianemi \\
& pozłocistemi, przez J.O.X.J.M. Konstantyna Szaniawskiego biskupa krakow- \\
& skiego oddany. Ad usum processionum in ecclecsia, kijów dwa tylko o dwóch \\
& drzewcach.
\end{tabular}

2. Baldachim na lamie białej, z kwiatami wielkiemi czerwonemi, z kaletkami tejże materyi, z galonkiem i kutasikami. Tego tylko do chorych używają.

\begin{tabular}{ll}
\hline Lp. & Baldachimy procesyjne $\mathbf{z}$ roku $\mathbf{1 7 9 1}$ \\
\hline 1. & $\begin{array}{l}\text { Baldachim nowy lamowy biały, o sześciu słupkach czyli drążkach posrebrza- } \\
\text { nych z gałkami wyzłacanemi drewnianemi. }\end{array}$ \\
\hline 2. & $\begin{array}{l}\text { Baldachim z lamy złotej, wokoło złotą frandzlą obwiedziony, tego używają } \\
\text { na processyjach po kościele cum Sanctissimo. }\end{array}$ \\
\hline
\end{tabular}

3. Baldachim stary na lamie białej, z kwiatami wielkiemi czerwonemi, z kaletkami tejże materyi, z galonkiem i kutasikami. Tego do chorych tylko używają.

84. Inwentarze skarbca katedry krakowskiej z lat 1702..., dz. cyt., s. 79, 183, 249-250. 


\section{Bibliografia}

Źródła

\section{Archiwum Kurii Metropolitalnej w Krakowie}

a) AV 8 - Visitatio quindecim decanatuum, nempe: Skavinensis, Zathoriensis, Novi Montis, Skalensis, Wrocimoviensis, Adreoviensis, Kijensis, Paczanoviensis, Oswiecimensis, Żywiecensis, Witoviensis, Skoliensis, Opatovecensis, Wielicensis et Plesnensis a Peril. et R.D. Nicolao Oborski, episcopo Laodicensis, suffraganeo, archidiacono, vicario in spiritualibus generali Cracoviensi in annis $1663-1665$ expedita.

b) AV 16 - Visitatio ecclesiarum decanatum Zathoriensis et Oswiecimiensis et Zywecensis per Perillustrem olim ac R[evere]ndum Dominum Remigium Suszycki, can[oni]cum Cra[coviensem], specialiter deputatum, anno 1709 et 1709 expedita et peracta.

c) AV 35 - Visitatio ecclesiarum parochialium in decanatibus Oswiencimensis et Zathoriensis a.D. 1747/1748.

d) AV 36 - In nomine Domini. Amen. Visitatio ecclesiarum parochialium, praebendarum, capelarum, hospitalium atque confraternitatum, nec non beneficiorum in decanatu Scavinensis foraneo, diaecesis, archidiaconatus et officialatus Cracoviensis existentium, ex speciali mandato Celssisimi principis Illustrissimi et Reverendissimi Domini Andreae Stanislai Kostka in Załuskie Załuski, Dei et Ap[osto]licae Sedis gratia episcopi Cracoviensi, ducis Severiae, per me Thomam Muszynski JU et Ph[ilosoph]iae Doctorem et profesorem, ecclesiarum collegiatae s. Annae Cracoviae canonicum, parochia lis sancti Nicolai ad Cracoviam praepositum, delegatum extraordinarium visitatorem, a[nno] D[omi]ni 1747.

e) AV 52 - Visitatio Decanatus Neoforiensis a.D. 1765.

f) AVCap. 61 - Visitatio archidiaconatus Cracoviensis per Illustrissimum et Reverendissimum D[om]inum Michaelem Kunice Kunicki episcopum Arsinoensem, suffraganeum et archidiaconum pro tunc Cracoviensem, Annie infrascriptis peracta. 


\section{Archiwum Parafialne w Polance Wielkiej}

a) Inwentarz sprzętów kościelnych z roku 1663.

b) Descrypcya kościoła Polońskiego pod tytułem Świętego Mikołaja

Biskupa Mireńskiego przez Jaśnie Wielmożnego IMCi Pana Kaspra na Cieni Cieńskiego Łowczego Nadwornego koronnego kolatora d. 11 Stycznia Roku P. 1734. X Sebastyanowi Żurkowskiemu Plebanowi teraźniejszemu conferowanego dawno już circiter intra et extra cum attinentijs zdezelowanego, dopieroż przez tegoż X. Żurkowskiego Plebana Introdukcyi własnym jego kosztem y straniem a fundamentis podważanego.

c) Spis Aparatów Kościelnych w Polance Wielkiej w Roku 1852.

d) Spis wydatków znaczniejszych, na kościół, rzeczy kościelne, Reperacyje Plebanii, budynków gospodarskich w Polance Wielkiej, przez ks. Jana Antosiewicza od Roku 1841. Własnym kosztem uskuteczniony, t. 19.

\section{Archiwum klasztoru ss. Norbertanek w Imbramowicach}

Inwentarz sprzętów kościelnych w kościele w Imbramowicach z 1862 roku.

\section{Archiwum Wojewódzkiego Urzędu Ochrony Zabytków w Krakowie}

a) Bielany koło Kęt, Baldachim procesyjny - Karta ewidencyjna zabytku ruchomego.

b) Łapsze Niżne, Baldachim procesyjny - Karta ewidencyjna zabytku ruchomego.

c) Sidzina, Baldachim procesyjny - Karta ewidencyjna zabytku ruchomego.

Inne

Inwentarze katedry krakowskiej z lat 1586, 1620 i 1692, opr. A. Perzanowska, Kraków 2014.

Inwentarze skarbca katedry krakowskiej z lat 1702, 1761 i 1791, opr.

A. Perzanowska, Kraków 2016.

Ritualis sue Agendae Romano-Pragensis [...], Pragae 1700.

\section{Opracowania}

Baldachim procesyjny, w: Wawel 10oo-20oo. Skarby archidiecezji

krakowskiej, t. 2, Katalog, red. J. A. Nowobilski, Kraków 2000, s. 255.

Bochnak A., Buczkowski K., Rzemiosło artystyczne w Polsce, Warszawa 1971. Brückner A., Encyklopedia staropolska, t. 1: A-M, Warszawa 1937-1939.

Dobrowolski T., Sztuka Krakowa, Kraków 1959.

Katalog zabytków sztuki w Polsce, t. 1: Województwo krakowskie, red.

J. Szablowski, Warszawa 1953. 
Katalog zabytków sztuki w Polsce, t. 4: Miasto Kraków, cz. 2: Kościoły i klasztory śródmieścia 1, red. A. Bochnak, J. Samek, Warszawa 1971.

Katalog zabytków sztuki w Polsce, t. 4. Miasto Kraków, cz. 3: Kościoły i klasztory śródmieścia 2, red. A. Bochnak, J. Samek, Warszawa 1987.

Kumor B. S., Dzieje diecezji krakowskiej do roku 1795, t. 1, Kraków 1998.

Lileyko J., Regalia polskie, Warszawa 1987.

Łuszczkiewicz W., Baldachim, w: Encyklopedia staropolska ilustrowana, red. Z. Gloger, t. 1, Warszawa 1900, s. 98-101.

Mąkinia F., Pisarzak M., Baldachim, w: Encyklopedia katolicka, t. 1, red. F. Gryglewicz, Lublin 1985, kol. 1275-1276.

Nadolski B., Leksykon liturgii, Poznań 2006.

Odsiecz wiedeńska 1683. Wystawa jubileuszowa w Zamku Królewskim na Wawelu w trzechsetlecie bitwy. Tło historyczne i materiały źródłowe, t. 1-2, red. A. Franaszek, K. Kuczman, Kraków 1990.

Romanowicz B., Onna. Piękno - siła - ekstaza. Drzeworyty i malarstwo japońskie z kolekcji Muzeum Narodowego w Krakowie, Kraków 2017.

Rożek M., Królewska katedra na Wawelu, Warszawa 1981.

Ruciński H., Dzieje późnośredniowiecznego Spisza, w: Historia Scepusii, t. 1, red. A. Gabryś, S. A. Sroka, M. Starzyński, Bratislava-Kraków 2010, s. $330-541$.

Samek J., Polskie rzemiosło artystyczne. Czasy nowożytne, Warszawa 1984.

Skarby baroku - między Bratysława a Krakowem, red. T. Zaucha,

J. Wolańska, Kraków 2017.

Słownik terminologiczny sztuk pięknych, red. K. Kubalska-Sulkiewicz, M. Bielska-Łach, A. Manteuffel-Szarota, Warszawa 2005.

Sobol L., Kultura klasztoru ss. Norbertanek w Imbramowicach od poczatku do czasów najnowszych, Kraków 2007.

Trajdos T. M., Szkice z dziejów Zamagórza, Kraków 1991.

W przestrzeni smoka. Sztuka chińska w zbiorach Muzeum Narodowego w Krakowie, red. A. Biedrzycka, M. Kołpanowicz, Kraków 2015.

Zarys historii włókiennictwa do końca XVIII wieku na ziemiach polskich, red. J. Kamińska, I. Turnau, Wrocław-Warszawa-Kraków 1966.

Zabytki sztuki w Polsce. Małopolska, red. W. Bałus, J. Wolańska, Warszawa 2016.

Zieliński Ch., Sztuka sakralna, Poznań-Warszawa-Lublin 1960. 
Żmudziński J., Procesja Bożego Ciała we Fromborku prowadzona przez biskupa Michała Stefana Radziejowskiego, w: Święto baroku. Sztuka w służbie prymasa Michała Stefana Radziejowskiego (1645-1705), red. J. Żmudziński, Warszawa 2009, s. 78-83.

Żygulski Z. jr., Dzieje polskiego rzemiosła artystycznego, Warszawa 1987. 


\section{Abstrakt}

ks. Szymon Tracz

Zachowane baldachimy procesyjne na terenie

Małopolski z wieku XVII i XVIII

Słowa kluczowe:

baldachim procesyjny, Małopolska, tkanina, haft, procesja
Baldachimy procesyjne na terenie Małopolski w wieku XVII i XVIII przyjmowały formę dekoracyjnego daszku wykonanego zazwyczaj z tkaniny rozpiętej na stelażu, przymocowanego do ozdobnych drążków, co umożliwiało ich przenoszenie. Przede wszystkim baldachimów używano podczas procesji teoforycznych. Wykonywano je z zasady z nietrwałych materiałów, stąd też zachowało się ich tylko kilka. Na podstawie źródeł archiwalnych oraz zachowanych przykładów baldachimy procesyjne można podzielić ze względu na kształt na dwa rodzaje.

Pierwszy, najliczniejszy, stanowią baldachimy o drewnianym lub metalowym stelażu na rzucie prostokąta zbliżonego do kwadratu, zaopatrzone w dwa lub cztery drążki. Drugi to baldachimy owalne na jednym drążku w kształcie parasola. W obu grupach najistotniejszym elementem dekoracyjnym była tkanina rozpięta na stelażu tworząca podniebie oraz dach baldachimu, kształtująca także jego boki za pomocą falbany lub lambrekinu. Podniebie i dach baldachimu wykonywane były zasadniczo z dwóch różnych tkanin. Dach baldachimu najczęściej był płaski, ale występowały także przykłady o dynamicznych formach, czego przykład stanowi baldachim w Kacwinie z drugiej połowy XVIII wieku. Dodatkowo stosowano dekoracyjne uzupełnienia w postaci obszycia galonem, koronką, frędzlą, taśmami i haftem, a także chwostami. Najczęściej drzewce baldachimów były rzeźbione i malowane. Najlepszym przykładem klasycznego baldachimu barokowego stanowi najstarszy zachowany w Małopolsce baldachim z roku ok. 1663 w Polance Wielkiej lub baldachim wykonany z XVII-wiecznej tkaniny w kolegiacie św. Anny w Krakowie. Zdarzało się, że dach baldachimu był obwiedziony ażurowym, bogato rzeźbionym i złoconym obramieniem, jak np. baldachim z trzeciej ćwierci XVIII wieku w Krzywaczce lub w kościele św. Anny w Nowym Targu (2. poł. XVIII w.). Ciekawą grupę tworzyły baldachimy w całości drewniane dekorowane malowaną i złoconą snycerką, które zachowały się na Spiszu, 
w kościele we Frydmanie (2. poł. XVIII w.), Krempachach (2. poł. XVIII w.) i Trybszu oraz znany ze zdjęć archiwalnych niezachowany baldachim z końca XVIII wieku w Łapszach Niżnych. Zasadniczym elementem dekoracyjnym wymienionych baldachimów jest bogato rzeźbiony i złocony drewniany stelaż, do którego przytwierdzany był dach wykonany z tkaniny bądź z deski.

Drugi rodzaj baldachimów w formie rozkładanego i składanego parasola reprezentowała niezachowana obecnie XVIII-wieczna umbella w Bielanach k. Kęt.

Powstające w następnych stuleciach baldachimy generalnie przyjęły formę opartą na prostym drewnianym stelażu z tekstylnym dachem i bokami prostymi lub w formie lambrekinu. Spotykane są także rozwiązania, w których do elementów tekstylnych dodawano akcenty snycerskie. 


\section{Abstract}

ks. Szymon Tracz

Processional Canopies from the $17^{\text {th }}$

and $18^{\text {th }}$ Centuries

Preserved on the Area of Lesser Poland

Keywords: processional canopies, Lesser Poland, fabrics, embroideries, procession
During $17^{\text {th }}$ and $18^{\text {th }}$ centuries processional canopies took a form of a decorative canopy usually made of fabric stretched on a frame, attached to ornamental poles. As a result, this construction enabled people to carry those canopies. First of all, processional canopies were used during theophoric processions. Such canopies were usually made of non-durable materials, and, therefore, only a few of them are still preserved. Based on information provided in various archival sources as well as remaining examples of processional canopies, one can divide them, due to their shape, into two types.

The first type that is also the most numerous are canopies with a wooden or metal frame on a rectangular projection that is close to the square, with two or four poles. The second type are oval canopies in the shape of an umbrella, set on single poles, with an example of the $18^{\text {th }}$-century canopy in Bielany near Kęty.

In both types, the most important decorative element was fabric stretched on a frame that formed an inside ceiling of a canopy as well as its top, also forming its sides with a frill or pelmet. Generally, the inside ceiling and the top of the canopy were made of two different kinds of fabrics. The top of the canopy was usually flat, but there were examples of more dynamic forms, e.g. a canopy from the $2^{\text {nd }}$ half of $18^{\text {th }}$ century in Kacwina. Also, some decorative elements such as braids, laces, fringes, tapes, embroideries and tassels were used. Canopy poles were carved and painted. The best examples of a classic baroque canopy are the oldest remaining canopy in Lesser Poland dated approximately for 1663 in Polanka Wielka and a canopy made of the $17^{\text {th }}$-century fabric in the church of St. Anna in Kraków. Sometimes the top of a canopy was surrounded with openwork, a richly carved and gilded frame, such as a canopy from the $3^{\text {rd }}$ quarter of the $18^{\text {th }}$ century in Krzywaczka or in the church of St. Anna in Nowy Targ $\left(2^{\text {nd }}\right.$ half of $18^{\text {th }}$ century). 
An interesting type of canopies were the canopies made entirely of wood and decorated with painted and gilded woodcarvings. The examples of such canopies include the canopies preserved in Spisz, in the church in Frydman ( $2^{\text {nd }}$ half of $18^{\text {th }}$ century), in Krempachy ( $2^{\text {nd }}$ half of $18^{\text {th }}$ century) and Trybsz and, last but the least, a well-known from archival photographs but currently non-existing canopy from the end of the $18^{\text {th }}$ century in Łapsze Niżne. The most important decorative elements of these canopies are richly carved and gilded wooden frames with their tops made of fabric or plank.

The second type of canopies in the shape of an open and folded umbrella is represented by a currently non-existent $18^{\text {th }}$-century umbrella in Bielany near Kęty.

The canopies from the following two centuries mostly took a shape based on a simple wooden frame with a textile top and straight sides or on a form of a pelmet. Also, there are examples of canopies in which wood carvings are added to the textile elements. 